Vietnam Journal of Earth Sciences 36 (2014) 489-496

\title{
Changes in the autumn precipitation and tropical cyclone activity over Central Vietnam and its East Sea
}

\author{
S.-Y. Simon Wang*1,2 ${ }^{1,}$ Parichart Promchote ${ }^{2}$, Luu Hong Truong ${ }^{3}$, Brendan Buckley ${ }^{4}$, Rong Li $^{1}$, Robert \\ Gillies ${ }^{1,2}$, Nguyen Tran Quoc Trung ${ }^{3}$, Biin Guan ${ }^{5}$, Ton That Minh ${ }^{6}$ \\ ${ }^{1}$ Utah Climate Center, Utah State University, Logan, Utah, USA \\ ${ }^{2}$ Department of Plants, Soils, and Climate, Utah State University, Logan, Utah, USA \\ ${ }^{3}$ Southern Institute of Ecology, Vietnam Academy of Science And Technology, Ho Chi Minh City, Vietnam \\ ${ }^{4}$ Lamont-Doherty Earth Observatory, Columbia University, Palisades, New York, USA \\ ${ }^{5}$ School of Forestry \& Resource Conservation, National Taiwan University, Taipei, Taiwan \\ ${ }^{6}$ International Center for Tropical Highland Ecosystems Research, Bidoup Nui Ba National Park, Vietnam
}

Accepted 26 December 2014

\section{ABSTRACT}

Central Vietnam is particularly vulnerable to the impacts of climate change, with all of its incumbent socioeconomic and ecological consequences. This is due in part to the autumn timing of the peak rainfall season in Central Vietnam, at a time when tropical cyclones are most likely to make landfall. We conducted climate diagnostic analyses using meteorological and tropical cyclone data to understand the changing patterns of autumn rainfall and tropical cyclones, revealing an intensification of precipitation over Central Vietnam since the beginning of the $20^{\text {th }}$ century that is associated with increased tropical cyclones in the adjacent sea. A warming of the sea surface temperature (SST) and enhanced southerly low-level winds are coincident with the above noted increase in rainfall and tropical cyclones. The underlying regional SST and circulation patterns are part of a hemispheric-scale change in the general circulation, i.e. a La Nina-like SST anomaly and a strengthened Walker circulation with the ascending branch located near Vietnam and far-western Pacific. We make the case with this paper that increasing autumn rainfall and tropical cyclones should be taken into account any mitigation and adaptation plans anticipated for Central Vietnam.

Keywords: Climate change, tropical cyclone, precipitation increase, extreme events, sea surface temperature

(C) 2014 Vietnam Academy of Science and Technology

\section{Introduction}

One of the largest concerns about climate change in Vietnam is an increase in the frequency of extreme weather events as well as the rising sea level (Neil Adger, 1999; Koetse and Rietveld, 2009), both of which may lead to loss of life and

${ }^{*}$ Corresponding author, Email:simon.wang@usu.edu property. The recent devastation in the Philippines by the Super Typhoon Haiyan in November 2013 demonstrated the type of extreme events that Vietnam might encounter in its coastal regions: i.e. widespread flooding, extremely high winds, and storm surges - these being compounded by the rising sea level. This situation poses a significant threat to the lives, properties, and ecosystems in Central Vietnam during its peak typhoon season 


\section{S.-Y. Simon Wang, et al./Vietnam Journal of Earth Sciences 36 (2014)}

from October to November. Recent research (Murakami et al., 2011; Chen, J et al., 2012; Yang et al., 2012) has found that late-summer typhoons initiated between Vietnam and the Philippine have become increasingly frequent since 1995, and the amount of rain associated with typhoons may also increase due to increasing sea surface temperature (SST) supplying more moisture and heat into the air. Since over two-thirds of the OctoberNovember typhoons that affect Vietnam develop west of the Philippines (Chen, J et al., 2012), their increased frequency and intensity is of grave concern.

Various international organizations have identified Central Vietnam as one of the most vulnerable places facing significant socioeconomic impacts of climate change (McElwee, 2012). According to the WWF-Indochina Programme (WorldBank, 2001), Central Vietnam belongs to the globally significant landscapes where a great majority of endemic species is potentially at severe risk in the short term, and at high risk in the long term. However, most climate change-related studies for Vietnam have been limited to social science and human perception, while the physical mechanisms and their impacts have received little attention (Buckley et al., 2014). With this paper we provide a climate diagnostic analysis of central Vietnam's precipitation regime change and tropical cyclone characteristics, followed by discussion of potential consequences and best practices that may help this vulnerable region adapt to potentially damaging changes in the regional climate.

\section{Climate Data}

We obtained monthly global precipitation data from the National Oceanic and Atmospheric Administration (NOAA)'s Precipitation Reconstruction over Land (PREC/L) (Chen, $M$ et al., 2002) for the period 1948-2014; this gridded dataset is based on the gauge observations with a spatial resolution of $1.0^{\circ} \times 1.0^{\circ}$. For wind fields, we used the $20^{\text {th }}$ Century Reanalysis driven by observed sea level pressure and SST (Compo et al., 2011), which has a resolution of $2^{\circ} \times 2^{\circ}$ and covers the time period 1948-2012. The six-hourly Best Track typhoon record was obtained fromthe US Navy's Joint Typhoon Warning Center
(JTWC) (http://www.usno.navy.mil/JTWC/). We utilized the NOAA Extended Reconstructed SST V3b (Smith et al., 2008) that has a resolution of $2.0^{\circ} \times 2.0^{\circ}$ for the period 1854-present, and also used the Niño-3.4 index obtained from the NOAA's Climate Prediction Center (http://www.cpc.ncep.noaa.gov/products/analysis_ monitoring/ensostuff/detrend.nino34.ascii.txt).

\section{Climatology of the autumn rainy season}

Figure 1 shows the climatological wind and precipitation fields averaged for OctoberNovember, illustrating that these two months serve as the major rainy season in Central Vietnam. The East Asian winter monsoon high-pressure cell sits to the north of Vietnam, while a region of tropical low pressure sits to the south. The result is strong pressure gradient providing steady onshore winds that interact with the orography over Central Vietnam, generating low clouds and persistent rainfall there. During October-November, tropical cyclones that have developed in the Vietnam East Sea or in the Philippine Sea and move directly towards Central Vietnam (orange tracks in Figure 1).

Moreover, when cold surges develop and interact with the tropical warm water, the so-called cold-surge vortex tend to form and migrate westward (Chang et al., 2005). Such vortices, whose vorticity-center tracks are shown in Figure 1 (gray dashed lines), can also result in heavy precipitation events in Central Vietnam oftentimes without reaching the intensity of typhoons. This is the result of the combined effects of cold surge flows from the northeast and the tropical depression in the southeast, which enhance the moisture transport from the depression into the hills of Central Vietnam. Previous research (Yokoi and Matsumoto, 2008; Yen et al., 2011) has pointed out that East Asian cold surges combined with tropical easterly waves or depressions have resulted in extreme rainfall in the past, for example the November 1999 event that flooded thecity of Hue (Yen et al., 2011). Apparently, any change in the easterly flows at the lower troposphere would contribute to rainfall variability in Central Vietnam. 


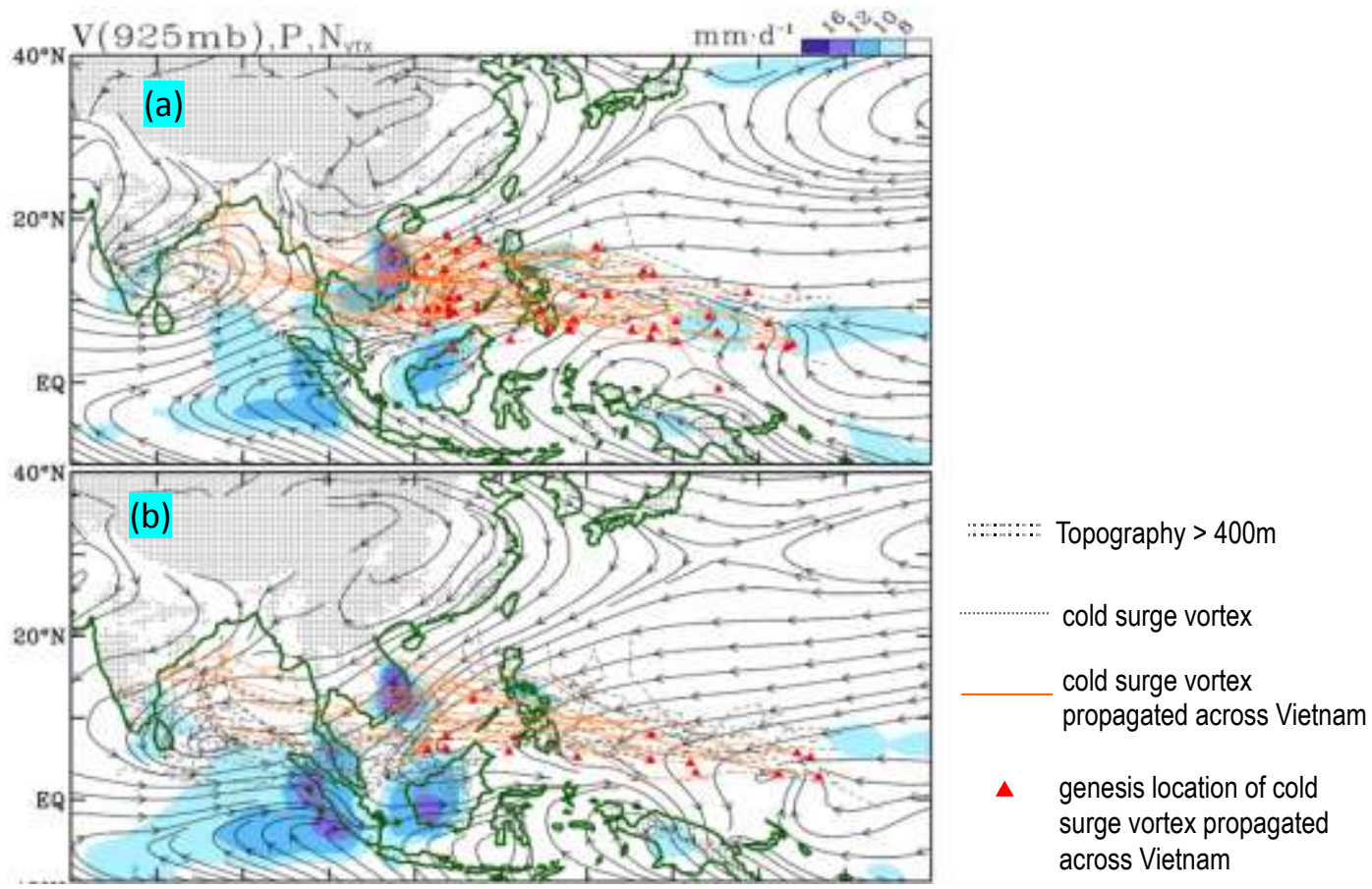

Figure 1. Climatological (1988-2005) 925-mb winds as streamlines and precipitation in (a) October and (b) November overlaid with tropical cyclone tracks (orange) and cold-surge vortices (gray dashed) with the genesis location indicated; see also the legend below

\section{Precipitation regime change}

We produced the latitude-time diagrams of rainfall for October and November, shown in Figure 2 , by averaging rainfall across Vietnam in the longitudinal direction and plotting it for each year, overlaid with the corresponding monthly Nino-3.4 SST index. Despite its interannual fluctuation in magnitude, the location of the region of maximum precipitation remains centered around $15^{\circ} \mathrm{N}$ until 2000 , after which it has taken place about $1^{\circ}-2^{\circ}$ further north. At this time precipitation also intensified, a change that is illustrated by the linear trend pattern that expands with time (orange contours). Moreover, at this time there is also a clear signal of wet/dry frequency change. For the month of November the high rainfall used to occur every 8-12 years until the late 1990s, before increasing to every 3-5 years. In terms of the forcing of interannual variability, rainfall in October exhibits a significant and inverse correlation with the simultaneous Nino-3.4 index, signaling that the autumn development of La Nina/El Nino tends to cause high/low seasonal rainfall in Central Vietnam. This observation is consistent with a previous study that reported the La Nina linkage with high rainfall seasons in Central Vietnam (Yen et al., 2011). For November, however, this relationship was not consistent during the 1970s-early 1980s, suggesting influences from other climate factors such as interdecadal climate variability or abnormal tropical cyclone activity.

In addition to the modulation of $\mathrm{El} \mathrm{Nino/La}$ Nina on the precipitation anomalies, SST variations near the coast of Vietnam may also influence precipitation over Central Vietnam. An examination of the September-November SST anomalies over the domain of $110^{\circ}-120^{\circ} \mathrm{E}, 10^{\circ}$ $20^{\circ} \mathrm{N}$ (Figure 3) reveals a marked increase inthe SST during the late 1990s, as indicated by the step function change in 1997, consistent with the observed change in autumn precipitation over Central Vietnam as shown in Figure 2. Because late-summer typhoons that form over the East Sea of Vietnam have been observed to intensify and increase since 1995 (Tu et al., 2009; Chen, Y and Tang, 2012), Central Vietnam likely faces an increasing threat from fall-season typhoons should this trend continue. 


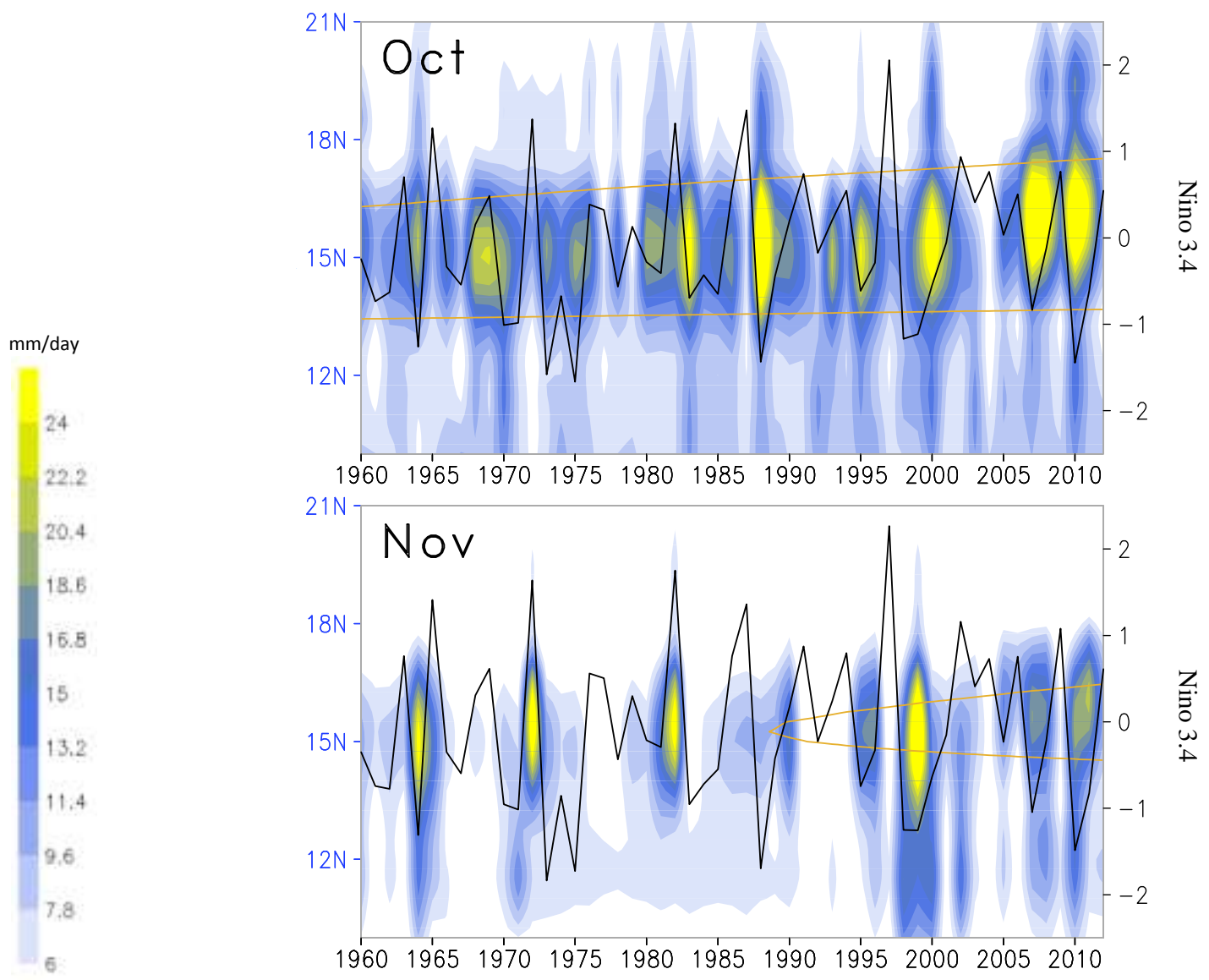

Figure 2. Latitude-time diagram of monthly precipitation averaged across mainland Vietnam for October (top) and November (bottom), overlaid with the linear trend contours at $20 \mathrm{~mm} / \mathrm{d}$ (golden contours) and the Nino-3.4 SST index (black line). Notice the regime change during the early 2000 s

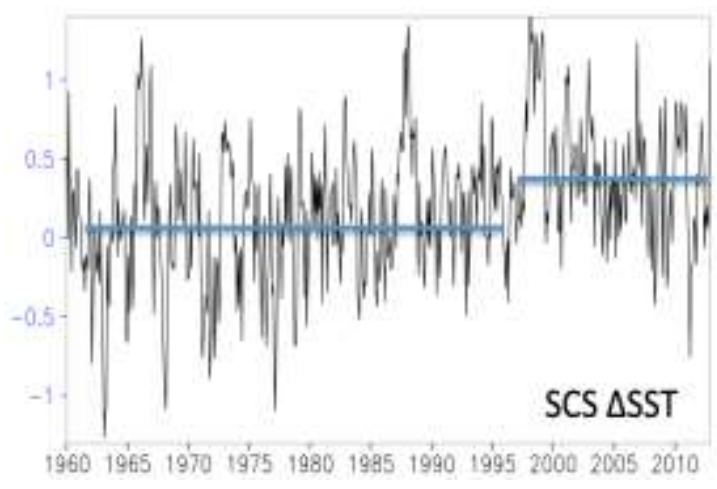

Figure 3. Monthly anomalies of SST within the SCS overlaid with a step function (blue horizontal lines) that indicates a regime change around 1997
The regional SST warming is part of the basinwide SST change that manifests itself in a La Nina-like pattern, as illustrated in Figure 4a and reported previously (Tung and Zhou, 2010; An et al., 2012). Increased SSTs since the late 1970s cover much of the Western and North Pacific while decreased SSTs encompass the tropical eastern Pacific and coastal water off western North America (Figure 4a). Correspondingly, the change in the low-level winds features intensified trade (easterly) winds across the tropical Pacific and a stronger subtropical gyre. Together with the east-west contrast in the SST anomalies, this wind pattern delineates a strengthened Walker circulation across the tropical Pacific that is similar to that reported by L'Heureux et al., 2013, with an 


\section{Vietnam Journal of Earth Sciences 36 (2014) 489-496}

ascending branch over the East Sea (other name: South China Sea; SCS) and western tropical Pacific. East of Vietnam, the low-level wind anomalies changed directions from easterlies to northerlies and then became southwesterlies along the East Asian coasts. Such anomalous SST and low-level winds enhance moisture transport and, arguably, leads to increased instability. To verify, we plotted in Figure $4 \mathrm{~b}$ the anomalies of convective available potential energy (CAPE - see caption) overlaid with the $850-\mathrm{hPa}$ anomalous wind fields, showing a band of increased CAPE along the Indochina Peninsula all the way to the water body that lies between Taiwan and thePhilippines, associated with the southerly andsouthwesterly wind anomalies. These collective changes in the dynamic and thermodynamic structures indicate a destabilized atmosphere that is increasingly conducive to moist convection.

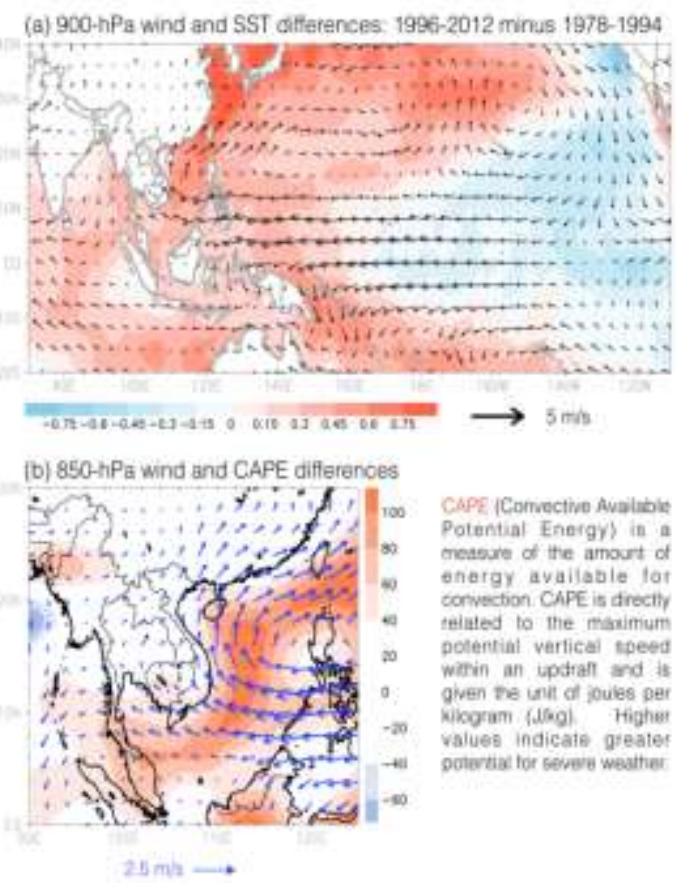

Figure 4. Era difference between the periods of 1996-2012 and 1978-1994 constructed for (a) 900-hPa wind vectors and SST (shadings) over the Asia-Pacific region, and (b) 850-hPa wind vectors and CAPE, the function of which is explained in the lower right

To examine further the impact of the aforementioned changes in the SCS, we compiled the areal frequency of 6-hourly tropical cyclone track records projected onto a $2^{\circ} \times 2^{\circ}$ grid mesh, following Wang and Clark, 2010. Figure 5 shows the era difference in the tropical cyclone frequency between the same time periods as in Figure 4 (i.e., 1996-2012 and 1978-1994). During the cyclone season (October-November) of Central Vietnam,an increase in the tropical cyclone frequency appears over the Gulf of Tonkin through Central Vietnam (indicated by arrow). This local increase in tropical cyclone frequency appears to be contradictory to the broader decrease in the eastern SCS and the Philippine Sea. However, when compared with Figure $4 \mathrm{~b}$, this result makes sense. Though the anticyclonic low-level wind anomalies occupy much of the coastal Vietnam, the Philippine Sea and the subtropical western Pacific, the southerly anomalous winds and the increased SST and CAPE together can enhance tropical cyclones either by prolonging their lifecycle or shifting their population westward towards Central Vietnam (Figure 5).

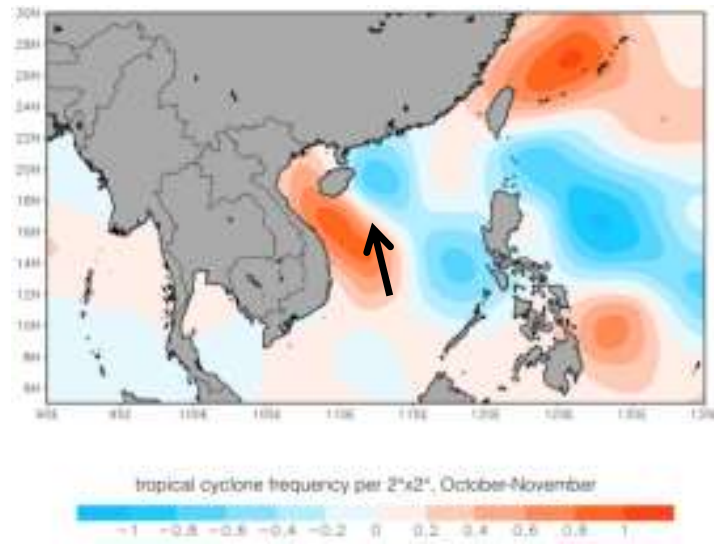

Figure 5. Epoch difference of the tropical cyclone areal frequency between the periods of 1996-2012 and 1978-1994 constructed from JTWC track records. The values indicate occurrence per 2-deg-square grid spacing

In addition to the changing tropical cyclone distribution noted above, the seasonal frequency of tropical cyclones that impact Vietnam has also changed. As shown in Figure 6a, the total number of tropical cyclones in the domain of $110^{\circ}-120^{\circ} \mathrm{E}$, $10^{\circ}-20^{\circ} \mathrm{N}$ during the two periods $1995-2014$ and 1975-1994 indicate two important changes: (i) the tropical cyclone season has 'expanded' with increased cyclones in September, November and December accompanied by decreased cyclones in June and July and; (ii) the peak tropical cyclone 


\section{S.-Y. Simon Wang, et al./Vietnam Journal of Earth Sciences 36 (2014)}

season has shifted from October to November.Upon further examination into different tropical cyclone scales, Figure $6 \mathrm{~b}$ shows that tropical depressions (with the maximum sustained wind speed under $33 \mathrm{kts}$ ) has undergone a pronounced increase by threefold throughout the

(a) tropical cyclone frequencies

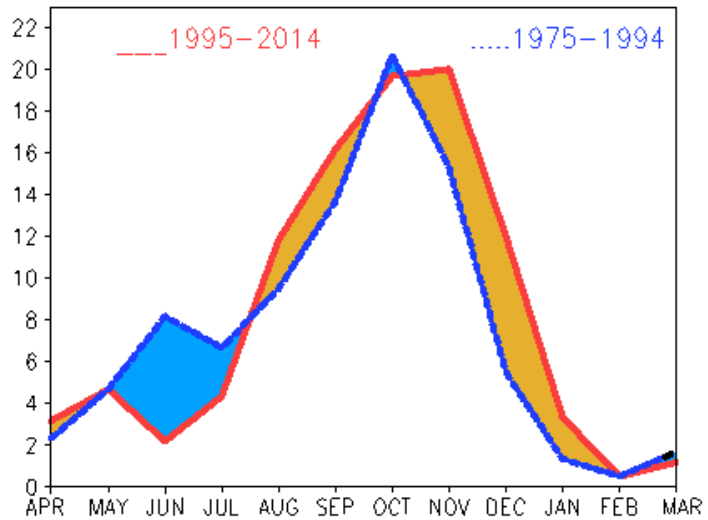

(b) tropical depression frequencies

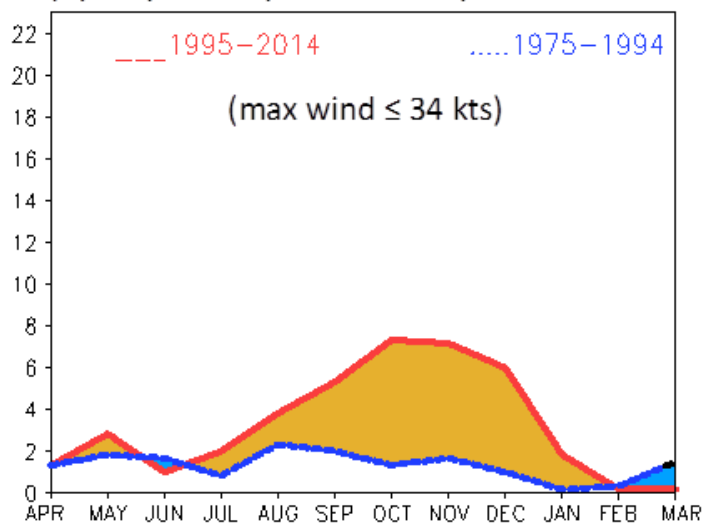

\section{Summary and discussion}

Vietnam as a whole is ranked among the 10 most vulnerable countries to climate change, and the damage caused by extreme weather/climate events has increased substantially since 1995 (Yuen and Kumssa, 2010). Future adaptation and mitigation strategies for these events require detailed scientific information on likely climate change. Here we investigated the changing precipitation characteristics in Central Vietnam during its major rainy season in OctoberNovember using climate diagnostic analysis coupled totyphoon track data. The analysis
September-December season, while Figure 6c shows that hurricane-forced tropical cyclones (or typhoons with the maximum sustained wind speed exceeding $65 \mathrm{kts}$ ) exhibit a clear phase shift with reduced number in summer and increased number in winter.

Figure 6. Epoch difference that is shaded between the periods of 1995-2014 (red) and 1975-1994 (blue) constructed for the seasonal distribution (monthly frequency) of tropical cyclones within the East Sea (aka South China Sea). The month is determined by tropical cyclogenesis day

\section{(c) typhoon frequencies}

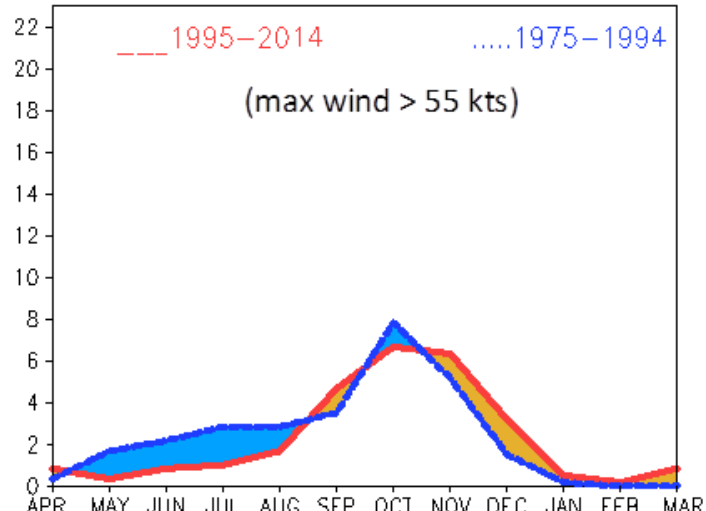

indicates an intensification of rainfall both in the amount and variability since the beginning of the $20^{\text {th }}$ century, and the fact that such a change is linked to increased SST and southerly wind anomalies off the coast of Vietnam. The troposphere over the SCS has also become increasingly unstable as is evident by increased CAPE and tropical cyclone frequency. Since SST plays an important role in driving the large-scale circulation change, and the changes in SST (as shown in Figure 4a) are linked to anthropogenic climate warming, it is reasonable to conclude that the post-1970 increase in the global temperature 
Vietnam Journal of Earth Sciences 36 (2014) 489-496

has contributed to the observed change in the October-November precipitation and tropical cyclone activity over Central Vietnam.

The reported increases in precipitation and tropical cyclones over Central Vietnam have immediate impacts on storm surge, i.e. one of the most destructive systems associated with a tropical cyclone that threatens the coastal communities. The occurrence of storm surge in a changing climate with increased precipitation and tropical cyclones will almost certainly result in more vulnerability to coastal ecosystems and to society as a whole. In addition, the complexity of the society-ecology-climate interactions in Central Vietnam is further compounded in such the semiarid area of Phan Rang - Phan Thiet in Central Vietnam that comprises desert landscapes and man-made agricultural ecosystems; this societyecology system is already stressed in this region due to a long dry season that persists for 8 months. Under the hardship of the long dry season and sandy soil, local farming community relies on forest products as the major household income source, including illegal harvests ${ }^{1}$. The reduction of forests have resulted in a more barren land, further stressing agricultural cultivation as well as the likelihood of increasing mudslides in the face of torrential rains. The changing rainfall pattern and the shifted seasonal cycle of tropical cyclones, as reported here, have and will further exacerbate and complicate the region's state both naturally and agriculturally and so, it would be prudent to adopt practical strategies for mitigation and adaptation.

\section{Acknowledgement}

This study was supported by the United States Agency for International Development Grant (USAID) EEM-A-00-10-00001 and the NASA Grant NNX13AC37G. Brendan Buckley was funded by the National Science Foundation Grants GEO 09-08971 and AGS 130-3976. The involvement of Luu Hong Truong and Nguyen Tran Quoc Trung isfunded by the project

${ }^{1}$ Such excessive harvests have led to near extinction of many plant and animal species in the wild (e.g., palms trees whose leaves are the key material of the traditional conical leafy straw hat, or harzelsterculia whose valuable gum is harvested from the trunk for soft drinks and medicinal treatment).
VAST.HTQT.HOAKY.01/12-13. Constructive comments provided by two anonymous reviewers are highly appreciated.

\section{References}

An, S.-I., J.-W. Kim, S.-H. Im, B.-M. Kim, and J.-H. Park, 2012: Recent and future sea surface temperature trends in tropical Pacific warm pool and cold tongue regions, Clim. Dynamics, 39(6), 1373-1383.

Buckley, B. M., R. Fletcher, S.-Y. S. Wang, B. Zottoli, and C. Pottier, 2014: Monsoon extremes and society over the past millennium on mainland Southeast Asia, Quaternary Science Reviews, 95(0), 1-19.

Chang, C., P. A. Harr, and H.-J. Chen, 2005: Synoptic disturbances over the equatorial South China Sea and western Maritime Continent during boreal winter, Mon. Wea. Rev., 133(3), 489-503.

Chen, J., R. Wu, and Z. Wen, 2012: Contribution of South China Sea tropical cyclones to an increase in southern China summer rainfall around 1993, Advances in Atmospheric Sciences, 29, 585-598.

Chen, M., P. Xie, J. E. Janowiak, and P. A. Arkin, 2002: Global Land Precipitation: A 50-yr Monthly Analysis Based on Gauge Observations, Journal of Hydrometeorology, 3(3), 249-266.

Chen, Y., and D. Tang, 2012: Eddy-feature phytoplankton bloom induced by a tropical cyclone in the South China Sea, International Journal of Remote Sensing, 33(23), 7444-7457.

Compo, G. P., J. S. Whitaker, P. D. Sardeshmukh, N. Matsui, R. J. Allan, X. Yin, B. E. Gleason, R. S. Vose, and E. al., 2011: The Twentieth Century Reanalysis Project, Q. J. Roy. Meteor. Soc., 137, 1-28.

Koetse, M. J., and P. Rietveld, 2009: The impact of climate change and weather on transport: An overview of empirical findings, Transportation Research Part D: Transport and Environment, 14(3), 205-221.

L'Heureux, M. L., S. Lee, and B. Lyon, 2013: Recent multidecadal strengthening of the Walker circulation across the tropical Pacific, Nature Clim. Change, 3(6), 571-576.

McElwee, P. D., 2012: Payments for environmental services as neoliberal market-based forest conservation in Vietnam: Panacea or problem?, Geoforum, 43(3), 412-426.

Murakami, H., B. Wang, and A. Kitoh, 2011: Future Change of Western North Pacific Typhoons: Projections by a $20 \mathrm{~km}$ Mesh Global Atmospheric Model*, J. Climate, 24(4), 1154-1169. 


\section{S.-Y. Simon Wang, et al./Vietnam Journal of Earth Sciences 36 (2014)}

Neil Adger, W., 1999: Social vulnerability to climate change and extremes in coastal Vietnam, World Development, 27(2), 249-269.

Smith, T. M., R. W. Reynolds, T. C. Peterson, and J. Lawrimore, 2008: Improvements to NOAA's Historical Merged Land-Ocean Surface Temperature Analysis (18802006), J. Climate, 21(10), 2283-2296.

Tu, J.-Y., C. Chou, and P.-S. Chu, 2009: The abrupt shift of typhoon activity in the vicinity of Taiwan and its association with western North Pacific-East Asian climate change, J. Climate, 22(13), 3617-3628.

Tung, K.-K., and J. Zhou, 2010: The Pacific's response to surface heating in $130 \mathrm{yr}$ of SST: La Niña-like or El Niñolike?, J. Atmos. Sci., 67(8), 2649-2657.

Wang, S.-Y., and A. J. Clark, 2010: Quasi-decadal spectral peaks of tropical western Pacific SSTs as a precursor for tropical cyclone threat, Geophys. Res. Lett., 37(21), L21810.
WorldBank, 2001: WWF Indochina Program, edited by W. Bank, http://mabvietnam.net/WWF Indochina Programme.htm.

Yang, L., Y. Du, S. Xie, and D. Wang, 2012: An interdecadal change of tropical cyclone activity in the South China Sea in the early 1990s, Chinese Journal of Oceanology and Limnology, 30, 953-959.

Yen, M.-C., T.-C. Chen, H.-L. Hu, R.-Y. Tzeng, D. T. DINH, T. T. T. NGUYEN, and C. J. Wong, 2011: Interannual variation of the fall rainfall in Central Vietnam, J. Meteor. Soc. Japan (気象集誌). 第 2 輯, 89, 259-270.

Yokoi, S., and J. Matsumoto, 2008: Collaborative effects of cold surge and tropical depression-type disturbance on heavy rainfall in central Vietnam, Mon. Wea. Rev., 136(9), 3275-3287.

Yuen, B. K. P., and A. Kumssa, 2010: Climate Change and Sustainable Urban Development in Africa and Asia, Springer, $262 \mathrm{pp}$. 